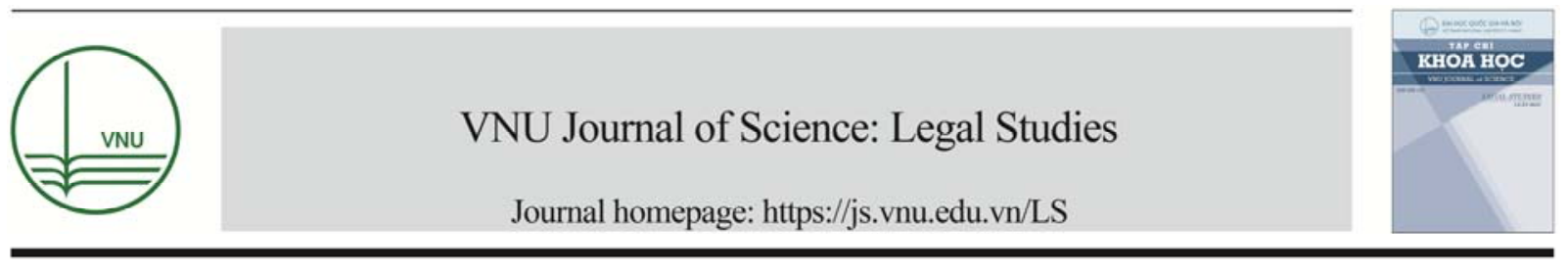

\title{
The Protection of Employee according to Taiwan Labour StandardsAct
}

\author{
Geng-Shenq Lin* \\ The College of Law, Tunghai University, Taiwan \\ Received 13 June 2018 \\ Revised 19 June 2018; Accepted 21 June 2018
}

\begin{abstract}
Established on July 30, 1984, the Taiwan Labour Standards Act (LSA)is the most important law that protects labourers in Taiwan. It was only after the LSA had been passed that the systematic researches on labour law actually began. As the LSA is a relativly new law, a number of its conceptionsare still vague; therefore, their application has caused certain difficulties. In this context, the Judiciary plays a decisive role. But, the common practice is that the judge frequently cites the scholars' opinions to support his decision. This article explains how the judiciary cooperates with the scholars to give better answers, especially to protect the employee, through defining "employee", "employee", in relation to wages, working hours and dismissals. Overall, we agree with the famous German scholar Gallmmilscheg on his saying "Richterrecht bleibt unserer schicksal" ("Judiciary remains our destiny") and the scholars will always make their contributions to this matter.
\end{abstract}

Keywords: LSA, employee, employer, wage, working hours, dismissal.

\section{The "employee"}

The Taiwan Labor Standards Act (hereinafter LSA) ${ }^{1}$, which followed the Japanese LSA as its model and was established in 30 , July 1984 , is the most important law that protects employees in Taiwan. The LSA is the milestone of Taiwan Labor Law Legislation. It stipulates the most important contents concerning the labour contract,

\footnotetext{
* Tel.: 84-86-4-2359012136625

Email:gslin@thu.edu.tw

https://doi.org/10.25073/2588-1167/vnuls.4162

${ }^{1}$ For the English translation of LSA, see http://law.moj.gov.tw/Eng/LawClass/LawContent.aspx?P $\underline{\mathrm{CODE}=\mathrm{N} 0030001}(2018 / 01 / 25)$.
}

which has already been amended 19 times, and the latest amendment was done on 31st January, 2018. This reflects the complex economic conflicts involved. And it was only after the LSA was passed that the systematic researches on labour law beginning. One must understand the LSA in order to understand how the employees are protected legally. Thus, in the following sections we will elaborate some important topics concerning LSA and by means of this we will also show the characteristics of Taiwan's labor laws.

\subsection{How to define "employee"}

The premise for the application of the Labor Standards Act and other labour laws is that the 
parties' contract belongs to the employment relationship. Therefore, how to define the "employee" becomes one of the most important and controversial question not only among the scholars, but also in the practice.

Art 2 Paragraph 1 of LSA stipulates: employee"means a person who is hired by an employer to work for wages." And Art 2 Paragraph 6 of the LSA provides that "labor contract means an agreement that establishes an employee-employer relationship." Because the LSA does not providemore information, the judiciary plays adecisive role to solve the problem [1].

According to the Judge made law, there are 4 specific criteria to define the "employee". In the civil decision of 1992 Tai-Shan-Tze No. 347 the Supreme Court-more precisely, the Supreme Court for civil and criminal law disputes only- for the first time has to face the problem of defining the "employee". Referring to the Opinion of the scholars the Supreme Court rules that the employee shall own the following characteristics: (1) personal subordinate; the employee is under the authority of the employer and obliged to obey the instructions of the employer; (2) the employee shall not use substitute; (3) economic subordinate; the employee does not work for his own, but for the purpose of the employer; (4) organizational subordinate; the employee is integrated in the organization of the employer and corporate with the other employees of the employer. For the purpose of protecting the employee, the employment contract is broadly to understand.

The 4 criteria proposed by the Supreme Court are notat all certain. For example, how to understand the economic subordinateor the organizational subordinate in a concrete case, and how shall these relate to the obligations of the parties [2]. However, the lack of clearer and convincing criteria and based on the authority of the Supreme Court the holding of this decision is soon followed by the judicial practice and generally accepted among the scholars.

\subsection{Interpretation no. 740 of Judicial Yuan}

But in less than 30 years the Supreme Court faces a serious challenge. It is very controversial whether the legal relationship between the Nan-Shang insurance company and his insurance agents is a labor contract. These lawsuits are estimated to involve hundreds of billions of NT dollars.

In the case of insurance agents vs Nan-Shan Insurance Company, the latter does not give the customer list to the agentsto work out, and the former have to find the potential customers on their own. The insurance agentscan usually decide freely, when and to whom to visit and their working regions are also not limited by Nan-Shan Insurance Company. The remuneration of the insurance agents depends mainly on the commission which is based on the premium charged. But on the other hand, in accordance with the Regulations Governing the Supervision of Insurance Agent - an administrative Ordnance of the Finance Ministry - the Nan-Shan Insurance company has strong directions and supervisions over their agents.

Based on the 4 criteria,the Supreme Administrative Court ruledin 3 decisions (2011 Pan-Tze No. 2117, 2226 and 2230) as the following:

- In accordance with the Regulations Governing the Supervision of Insurance Agent the Insurance company has strong direction and supervision over the agents,

- The agents shall pervade the service personally, they cannot use substitute,

- They provide the service not for their own, but for the business of the company,

- Most of their jobs must be done in the office of the insurance company through corporation with their colleagues, so they are employees of the Insurance.

To almost the same situations, the Taiwan High Court in civil decisionof 2012 Lau-ShanTze No. 21 come to the opposite conclusion, which was upheld by the Supreme Court in civil decision of 2012 Tai-Shan-Tze No. 1333, mainly based on the following reasons: 
-The personally, economically, or organizational dependence of the insurance agents shall be not directly based onthe administrative rules, e.g. the Regulations Governing the Supervision of Insurance Solicitors.

- The agreement between the two parties focuses on the completion of a certain job rather than on the command and supervision of appellee.

- The remuneration of the agent depends on the conclusion of the insurance contract and the collection of premiums, and if the contract of insurance has been terminated, the appellant should refund the remuneration received, which is quite different from the general contract of employment.

To the different opinions mentioned above, the Interpretation No. 740 of Judicial Yuan which has the task of unifying the interpretation of law- in 2017 adopts a position which is close to the Supreme Court and rules: Whether a service contract for the solicitation of insurance business between an insurance solicitor and the insurance company to which the solicitor belongs is a labor contract under Art 2 Subparagraph 6 of the Labor Standards Act shall depend on whether the service debtor (the insurance solicitor) may freely decide the manner of the provision of service (including working hours), and will bear business risks on own account (for example, the remuneration shall be calculated on the basis of insurance premium received from the solicited insurance). It cannot be determined directly in accordance with the Regulations Governing the Supervision of Insurance Solicitors [3].

\section{3. "De facto employment contract"}

To protect child labor Art 45 LSA stipulates: No employer shall employ any person under the age of fifteen. A contract violating a mandatory rulein general shall be null and void (Art 71 Civil Code). Accordingly a contract violating Art 45 LSA shall be null and void.
But whether this rule allows no exceptions, is doubtful. In the civil decision 1998 Tai-Shan-Tze No. 451 the Supreme Court has faced the following situation. The appellee hired a 14 years old boy(appellant) to help construction and cleaning up the wastes, by working the appellant was serious injured. The appellant requested compensations for occupational accident according to Art 59 LSA, which premises a valid employment contract between the parties. If acontract violating Art 45 LS Ashall be null and void, the appellant who should be protected by Art 45 LSA could not enjoy the compensations regulated by Art 59 LSA.

In the civil decision of 1998 Tai-Shan-Tze No. 451the Supreme Court ruled: Art 45 LSA stipulates: No employer shall employ any person under the age of fifteen. The objective is thatthe obligations Education is extended for nine years, and children are enrolled at the age of six and education is completed at the age of fifteen. Adhering to this provision in line with the education policy and with reference to relevant international conventions, this legislative objective is to protect persons under the age of 15. Therefore, if an employer hires a person under the age of 15 in violating this Art, and he might claim that the employment contract is invalid after the occupational accident and the employed person shall not enjoy the compensations which Art 59 provided, and this would violate the legislative intent. Base on the maxim "cessante ratione legis cessat ipsa lex'and the theory of 'de facto employment contract"- a reception from the German labour law, this judgment is positively evaluated in the doctrine [4].

\section{The "employee"}

\subsection{The definition of the employer and extension of the employer's liabilities}

Pursuant to the Art 2 Paragraph 2 the employer is "a business entity which hires workers, the responsible person of business 
operations, or the person who represents the business owner in handling labor matters."Based on the contractual privity, the contractor who makes an employment contract with the employee shall bear the employers contractual obligations. However, in order to protect the employee more effectively, the man who exercises the power of direction and supervision shall also bear the obligations of the employer [5]. For example, regarding the prevention of occupational accidents, to all the worker, including the"selfemployed workers, or other people engaged in work and directed or supervised by the responsible people in workplaces", the employer is also obliged to protect them from occupational accident. If the employer violates this obligation, he shall face the administrative penalty and assume the responsibility of tort law (Art 184 paragraph 2 Civil Code).

The above mentioned also applies to the problems of equality of Gender in employment (especially Art 3 Paragraph 3 and 5, Act of Gender Equality in Employment).

\subsection{The recognition of "double employment relationships"}

In theory, the same parties can establish many legal relationships at the same time. For protecting the employee this is also recognized by the Supreme Court. In civil decision of 2008 Tai-Shan-Tze No. 13, the Supreme Court has to face the following situation: The appellee (employee) was employed by the appellant company (Hong shin Shipping Company) from August 1, 2003 as an assistant to the general manager. Later, he was assigned to Beiliang Logistics, China, a joint venture established by the appellant and others in mainland China. The appellant still continues to pay the costs of labour insurance and health insurance for the appellee and the latter is still under the direction and supervision of the appellant; he shall report the work situation in China to the appellant company on a regular basis.

After the Beiliang company terminates the contract between Beiliang and appellee, the latter come back to Taiwan and request to be transferred to the original position, but was rejected and fired shortly afterwards. The Supreme Court ruled that"there is an indefinite labor contract between the appellant and the appellant and a second contractual relationship between the appellee and Beiliang Company. The Termination of the contractual relationship of the appellee and Beiliang Company does not mean that the contractual relationship of the appellee andappellant company also automatically be terminated. Without legal causes regulated in Art 11 and 12, the termination of the employment contract between the parties is void" [6].

\section{Wages}

Regarding the wages [7] the parties can freelynegotiated with each other. However, that such wages shall not fall below the basic wage. The basic wage shall be prescribed by the basic wage deliberation committee of the labor ministry and submitted it to the Executive Yuan for approval. (Art 21 Paragraph 1, 2) Wages shall be paid in the statutory, circulating currency and in full directly to the worker (Art 22). Neither gender discrimination nor the advance deduction of wages as penalty for breach of contract or as indemnity from the employer is allowed. (Art 25, 26). An employer shall pay worker overtime wages on the following basis:

- In the first 2 hours,at least 1.33 times of the regular hourly wage,

- In the 3rd to 4th hours, at least 1.66 times of the regular hourly wage,

- On the non-working day, two times the regular hourly wage. (Arta 24).

According to the official statistic of the financial ministry in Aug 2017, ${ }^{2}$ among ca 5

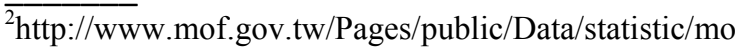
nthly/10604/\%E4\%B8\%AD\%E6\%96\%87\%E9\%9B\% BB\%E5\%AD\%90\%E6\%9B\%B8.pdf. (2018/05/12)
} 
Million employees, the income of 1.3 Million employees is 22 to 23 thousand NT per month, which corresponds to the standard of low salary income. Ca $33 \%$ of them are between age 21 to 30. This shows that "youth poverty" has become a serious problem.

Table 1. How much is the basic wage in recent year [8]

\begin{tabular}{|c|c|c|c|c|}
\hline Basic Wages & GDP (M) & $\begin{array}{c}\text { average } \\
\text { income/ Mon }\end{array}$ & $\begin{array}{l}\text { Basic wage/ } \\
\text { Mon }\end{array}$ & $\begin{array}{l}\text { Basic wage/ } \\
\text { average } \\
\text { income }\end{array}$ \\
\hline $\begin{array}{l}\text { From 16. Oct. 1997, 15,840 } \\
\text { NT/month, } 528 \text { NT/day, } 66 \\
\text { NT/hour }\end{array}$ & $8,717,241$ & 30459 & 15,840 & $52.00 \%$ \\
\hline $\begin{array}{l}\text { From 1. July } 2007,17,280 \\
\text { NT/month, } 95 \text { NT/hour }\end{array}$ & $\begin{array}{l}13,407,062 \\
(+53.80 \%)\end{array}$ & $\begin{array}{c}42148 \\
(+38.37 \%)\end{array}$ & $\begin{array}{c}17,280 \\
(+9.09 \%)\end{array}$ & $41.00 \%$ \\
\hline From 1. Jan. 2011, 17,880 & $14,312,200$ & 44160 & 17,880 & $40.49 \%$ \\
\hline NT/month, 98 NT/hour & $(+6.75 \%)$ & $(+4.77 \%)$ & $(+3.47 \%)$ & \\
\hline From 1. Jan. 2012, 18,780 & $14,686,917$ & 44739 & 18,780 & $41.98 \%$ \\
\hline NT/month, 103 NT/hour & $(+2.62 \%)$ & $(+1.31 \%)$ & $(+5.03 \%)$ & \\
\hline $\begin{array}{l}\text { From 1. Jan. 2013, } \\
\text { 19,047NT/month, } 109 \text { NT/hour, }\end{array}$ & $\begin{array}{l}15,230,739 \\
(+3.70 \%)\end{array}$ & $\begin{array}{c}46818 \\
(+4.65 \%)\end{array}$ & $\begin{array}{c}19,047 \\
(+1.42 \%)\end{array}$ & $40.68 \%$ \\
\hline $\begin{array}{l}\text { From 1. Jan. 2014, } \\
\text { 19,273NT/month, } 115 \mathrm{NT} / \text { hour, }\end{array}$ & $\begin{array}{l}16,111,867 \\
(+5.79 \%)\end{array}$ & $\begin{array}{c}49917 \\
(+6.62 \%)\end{array}$ & $\begin{array}{c}19,273 \\
(+1.19 \%)\end{array}$ & $38.61 \%$ \\
\hline $\begin{array}{l}\text { From } 1 \text {. July } 2015 \text {, } \\
20,008 \mathrm{NT} / \text { month, } 120 \mathrm{NT} / \text { hour }\end{array}$ & $\begin{array}{c}16,770,671 \\
(+4.09 \%)\end{array}$ & $\begin{array}{c}52042(+ \\
4.26 \%)\end{array}$ & $\begin{array}{c}20,008 \\
(+3.81 \%)\end{array}$ & $38.45 \%$ \\
\hline $\begin{array}{l}\text { From 1. Oct. 2016, } \\
\text { 126NT/hour }\end{array}$ & $\begin{array}{l}17,152,093 \\
(+2.27 \%)\end{array}$ & $\begin{array}{c}53128(+ \\
2.09 \%)\end{array}$ & $\begin{array}{c}20,008 \\
(+0.00 \%)\end{array}$ & $37.66 \%$ \\
\hline $\begin{array}{l}\text { From 1. Jan. 2017, } \\
\text { 21,009NT/month, 133NT/hour }\end{array}$ & $\begin{array}{l}17,408,956 \\
(+1.50 \%) \\
\text { (prognosis) }\end{array}$ & $\begin{array}{c}53539(+ \\
0.77 \%)\end{array}$ & $\begin{array}{c}21,009 \\
(+5.00 \%)\end{array}$ & $39.24 \%$ \\
\hline $\begin{array}{l}\text { From 1. Jan. 2018, } \\
22,000 \mathrm{NT} / \text { month, } 140 \mathrm{NT} / \text { hour }\end{array}$ & $\begin{array}{l}17,881,772 \\
(+2.72 \%) \\
\text { (prognosis) }\end{array}$ & $\begin{array}{c}54577(+ \\
1.94 \%)\end{array}$ & $\begin{array}{c}22,000 \\
(+4.72 \%)\end{array}$ & $40.31 \%$ \\
\hline
\end{tabular}

\section{The working hour}

\subsection{Definition}

The working time includes the period:(1)during which the employee actually provides service or (2) stays in the workplace, though not actually, but must provide service at any time (for example, the switchboard/ customer service personnel are staying at the workplace and waiting for the caller guest to inquire). However, concerning the "stand by time," (For example after work a physician can stay where he wants or do what he likes to do, but he must keep the handy turned on, and in emergency situations the hospital will call him back and he must return to the hospital within a certain period of time) if the employee is not called back to work, this period of time is excluded from the working time. [9]

But if the employee is required his/her stay in a specific place (usually a dormitory provided by the employer), where he can do what he wants to do (for example, eating, sleeping or watching TV...), but hehas to provide service immediately when an emergency occurs. Does this period of time, the 'on call time', belong to working time? 
Since the LSA gives no legal definition of the working time, the answer is left to the Judiciary and legal scholars. According the majority of the scholars this period of time is working time [10]. In the 1990s the decisions of the Supreme Court were inconsistent. In the cases of China Iron \& Steel Co., Ltd. vs Security officers, the Supreme Court in civil decision of 1997 Tai-Shan-Tze No. 1330 holds this is working time, but in civil decision of 1997 Tai-Shan-Tze No. 1330 the Supreme Court denies it.

In the recent years, the Supreme Court tends to identify this as a working Time. In civil decision of 2002 Tai-Shan-Tze No. 1842 the Supreme Court ruled that this period belongs to working time because the employee is still under the control und supervision of the employer. In civil decision of 2008 Tai-ShanTze No. 1358 the Supreme Court ruled: The purpose of the working Institution is to restrict employers from arbitrarily extending the working hours of employers. If the employee is still under the control and supervision of the employer, this period belongs to working time, no matter the employee does the same or different types of work as in regular working time. This conclusion coincides with the opinion of European Court of Justice in the decision of 3.10.2000 [Simap] and 9. 9. 2003 [Jaeger] [11].

\subsection{The overall situation of working time}

From the beginning the LSA (30 July 1984) provided that "the daily working hours of workers should not exceed eight hours and the total number of working hours per week should not exceed 48 hours."(Art 30). Since the amendment of 28 June 2000 "the total number of working hours every two weeks should not exceed eighty-four hours." That means the total number of working hours every 2 weeks was decreased by 12 hours. Since the amendment of 3June 2015"the regular working time of workers may not exceed eight hours a day or 40 hours a week."(Art 30). This means an employee shall have two regular days off every seven days. One day is a regular leave and the other one is a rest day (Art 36).

Table 2. The average working hours per person per month from 2012 to $2016^{3}$

\begin{tabular}{cc}
\hline Year, & $\begin{array}{c}\text { Working Hour, } \\
\text { Person/Month }\end{array}$ \\
\hline 2012 & $178.4 \mathrm{hr}$ \\
2013 & $177.0 \mathrm{hr}$ \\
2014 & $177.9 \mathrm{hr}$ \\
2015 & $175.3 \mathrm{hr}$ \\
2016 & $169.5 \mathrm{hr}$ \\
\hline
\end{tabular}

Table3. Non-working days 2013-2017

\begin{tabular}{ccc}
\hline Year & $\begin{array}{c}\text { Noworking } \\
\text { days }\end{array}$ & $\begin{array}{c}\text { Working } \\
\text { days }\end{array}$ \\
\hline 2012 & 112 & 254 \\
2013 & 115 & 250 \\
2014 & 114 & 251 \\
2015 & 115 & 250 \\
2016 & 116 & 250 \\
\hline
\end{tabular}

According to the official statistics of the Labour Ministry ${ }^{5}$, the average working hours per year in 2012 is 2141 hours. It is only lower than in Singapore with 2402 hours/year and Mexico with 2226 hours/year ${ }^{6}$, higherthan other

\footnotetext{
$\overline{3}$ https://www.dgbas.gov.tw/ct.asp?xItem $=40115 \& \mathrm{ctNo}$ $\mathrm{de}=3103 .(2018 / 05 / 12)$

${ }^{4}$ http://www.319papago.idv.tw/holiday/2012hr/2012_HR.html;

http://www.319papago.idv.tw/holiday/2013hr/2013_HR.html;

http://www.319papago.idv.tw/holiday/2014hr/2014_HR.html;

http://www.319papago.idv.tw/holiday/2015$\mathrm{hr} / 2015$ HR.html;

http://www.319papago.idv.tw/holiday/2016hr/2016_HR.html; http://www.319papago.idv.tw/holiday/2017hr/2017_HR.html.(2018/05/12)

${ }^{5}$ https://www.mol.gov.tw/media/2688327/\%E6\%88\%9 $1 \% \mathrm{E} 5 \% 9 \mathrm{C} \% 8 \mathrm{~B} \% \mathrm{E} 5 \% \mathrm{~B} 7 \% \mathrm{~A} 5 \% \mathrm{E} 6 \% 99 \%$ $82 \%$ E7\%B5\%B1\%E8\%A8\%88\%E5\%8F\%8A\%E5\%9 C\%8B\%E9\%9A\%9B\%E6\%AF\%94\%E8\%BC\%83\%Е 7\%A0\%94\%E6\%9E\%90.pdf.(2018/05/12)

${ }^{6}$ Regarding the compensation based on Article 59, which stipulates a no fault Liability for employer, the plaintiff's
} 
major countries of the OECD countries. That means Taiwan has the 3rd longest working hours in the world.

According to the latest statistic of the LaborMinistry $^{7}$, the average annual working hours in 2015 is 2104 hours. There is a decrease of 31 hours compared with the year 2013. In comparison with Singapore (2371 hours/year), Mexico (2246 hours/year) and South Korea (2113 hours/year), Taiwan's ranking is also dropped from No. 3 to No. 4.

\subsection{Taiwan-an overworked Island}

In the amendment, 27 Dec 1996, the new Art 84-1 LSA was added. Accordingly, when meeting the regulated requirements, some types of employee may arrange their own working hours through agreements with their employers. These agreements shall not subject to the restrictions imposed by Arts 30, 32, 36, 37 and 49 of the Act. The following two notorious cases may show the working time of the employee who cannot enjoy the protections the LSA.

Security staff belongs to Art 84-1 LSA regulated employee. In the civil decision of 2016 Tai-Shan-Tze No.376 the Supreme Court,the heir of the overworked employee requests the employer, Chien Shan Security Company,for compensation of the occupational accidents her father -the employee- suffered from ${ }^{8}$.

According to the contract between the parties:

- The regular working hours is 12 hours a day, every month 252 hours,

- The working hours can be up to 4 hours a day, up to 100 hours per month,

request is granted. The other requests, which base on the Article 184 Civil Code, which stipulates a negligence liability for Infringement responsibility, is rejected.

${ }^{7}$ https://www.mol.gov.tw/announcement/2099/29849/. (2018/06/04)

${ }^{8}$ Regarding the compensation based on Article 59, which stipulates a no fault Liability for employer, the plaintiff's request is granted. The other request, which base on the Article 184 Civil Code, which stipulates a negligence liability for Infringement responsibility, is rejected.
- The total working hours can be up to 352 hours,

- The actual working hours is between 288 to 300 hours per month.

In the civil decision of Taiwan High Court Tainan Branch 2013 Zhong-Lau-Shan-Tze No 1 , the plaintiff, a physician hired by the Chi May Hospital, who was prepared to take part in the first surgical operation on that day and collapsed in the corridor of the operating room. The physician had average 72 to 80 hours of overwork per month in the latest 6 months; andin four months beforeoccupational disease, he worked 298 hours per month. Being diagnosed as stroke which was caused by longterm overtime work and since to the contract the LSA do not apply, so he requested among others the compensation based on Art 184 Civil Code. His request is granted ${ }^{9}$.

\section{Dismissal}

An employment contract should be a nonfixed term contract, only if in nature for temporary, short-term, seasonal or specific work may be made as a fixed term contract (Art 9 Paragraph 1). Without the agreement of the parties, the employer may only dismissal the employee with the just causes, which are mainly regulated in Art 11 (4 specific types of the difficulties of the employers' businesses, incompetent of the employee), Art 12 LSA (the employee breach the contract). Under Art 11 LSA the employer may terminate the contract with a 10-to-30-days-period of advanced notice (Art 16), and the employershall issue severance pay with the maximum of 6 months average month wages. Under Art 12 LSA the employermay terminate the contract without advanced notice and no severance pay is required (Art 17).

Since the dismissal has considerable impacts on the rights and interests of workers,

\footnotetext{
$\overline{9}$ Comment on this decision, Lin, Geng-Schenq, An overwork physician, Yue Dan Judiciary Times, No. 38, Aug 2015, pp 48-55.
} 
and reference to the principle of proportion and the principle of good faith (Art 148 Civil Code), it is suggested by scholar, ${ }^{10}$ that the Ultima Ratio principle shall apply to dismissal. This means, dismissal may only be the last resort, an unavoidable means. Expressed differently, if the employer has milder means (e.g.warning, transfer or pay cut) to solve the problems (e.g. the unfulfilled duties) and we can also in general expect a normal employer to do so, then a dismissal, even it is in line with the legal text of Art 11 or 12, is null and void.

In the first decade of 21 Century, this theory is not judged uniformly in the jurisdiction. For example, at one hand it finds expressly recognition in the civil decision of 2007 TaiShan-Tze No. 2630 of the Supreme Court. At the other hand, this theory is repudiated in the civil decision of the Supreme Court in the civil decision of 2006 Tai-Shan-Tze No. 1692. The Supreme Court puts his opinion as follows: the provisions of Art 11, paragraph 2, allows the employer who did suffer an operating losses, or business contractions to dismissal the employee without consulting the employee to adjust his position. The opposite opinion would lead to the illegally restriction of the employers right to dismissal, which cannot find the basis in the Labour Standards Law, and shall be criticized.

In the latest decisions the Supreme Court trends to accept the theory. For example, in civil decision of 2017-Tai-Shan-Yze No 2468 the Supreme Court expresses his opinion as follows: "Art 11, paragraph 2, of the Labor Contract Law, shall base on a considerable period of time, especially the situation of profits and losses in recent years. A short-term revenue reduction or other temporary causes of income decreased which will not affect the survival of the business, or only one department suffers business contractions and the other departments

\footnotetext{
${ }^{10}$ See Lin, Geng-Schenq, On the Ultima Ratio principle of the dismissal, in Lin, Geng-Schenq, Labour Law Case Study (I), Taipei, 2002, pp 259-280. It also can see Chen, Yo-Yi, Termination of Labor Contracts, Ft Law Review, No. 169. February 2010. Pp 55-62.
}

still in normal operation, it shall not be allowed the employer to terminate the labor Contracts without first trying to transfer the employee to the other normally operating department. Based on the Ultima Ratio principle of the dismissal, only when the employer cannot continue to hire the employee, may the latter be dismissed. The appellant owns more than 30 years of work experience, with qualification of technology designers and so on. By mediating the labor dispute, the appellant also shows his willingness to be trained and transferred to other departments with job vacancies. The appellee rejected the request and directly terminated the employment contract. The dismissal was invalid".

\section{Conclusion}

The Taiwan Labor Standards Act (LSA), which followed the Japanese LSA as its model and was established in 30, July 1984, is the most important law that protects labors in Taiwan. And it was only after the LSA was passed that the systematic researches on labour law beginning. Comparing with e.g. the Civil law, the LSA is a relative young field and many conceptions were uncertain, so by its implementations we inevitablyhave to face many difficulties.To this the Judiciary plays the decisive role, but it has not to fight alone. As it is the common practice, at least in the obiter dictum, the judge frequently cites the scholars'opinions to support the decision. Especially if thereare no applicable rules, the well-grounded opinions of scholars are frequently deemed decisive and adapted by the court. So we see a harmonious corporation between the Judiciary and scholars which not only fulfill the ultimate goal of the LSA, the protection of the employees, but alsokeep itmore flexible and sensitive to the societal needs. Overall it seems to own both the features of the civil law and the Anglo-American law.Toimplement the LSA in a changing society, especially to protect the employee, we 
are allowed with a famous German scholar Gallmmilscheg to say "Richterrecht bleibt unserer schicksal" ("Judiciary remains our destiny") and the scholars will also make their contributions to this.

\section{References}

[1] Y. H. Hou, The Review on the Legislation of the Norm of Labor Contract-Lessons from Japan, Taipei University Law Review 83 (2012) 211.

[2] G. S. Lin, On the Subordination of the Employee, Labour Law Case Study(I), Hanlu Publisher, Taipei, 2002.

[3] G. S. Lin, Zhenq Bou, On the Interpretation No. 740 of Judicial Yuan, Yue Dan Judiciary Times 60 (2017) 43.

[4] G. S. Lin, From "de facto employment contract" to "failed employment contract", Labour Law Case Study (II), Wu-Nan Culture, Taipei, 2009.
[5] M. F. Ya, A Review on "the Same Employer" in Labor Standards Act, Taiwan Labor Quarterly 10 (2007) 32.

[6] G. S. Lin, On the Concept of the Employer and the Extension of his Obligations, Labour Law Case Study (II), Wu-Nan Culture, Taipei, 2009.

[7] Y. C. Lee, The Evolution and Trends of the Definition of Wages-Focus on Domestic Judicial Practice, Labor Law Journal 9 (2012) 1.

[8] GDP:

https://www.dgbas.gov.tw/point.asp?index=1,http s://www.stat.gov.tw/ct.asp?xItem $=37407 \& \mathrm{CtNod}$ $\mathrm{e}=3564 \& \mathrm{mp}=4$ Basic wages: https://www.mol.gov.tw/topic/3067/5990/13171/1 9154/ (2018/01/12).

[9] S. H. Lee, The New Era ofWorking Hour Law in Taiwan, Taiwan Labor Quarterly 43 (2015) 18.

[10] G. S. Lin, The on Call Time - the Regulations in EU Countries, Labour Standards Act - 30 years after its implementation, Labour Ministry(Ed), 2014, 237-257.

[11] G.S.Lin, On the Working Hours, National Lawyer 144 (2010) 23.

\title{
Bảo vệ người lao động theo Đạo luật Tiêu chuẩn Lao động Đài Loan
}

\author{
Geng-Shenq Lin \\ Học viện Pháp luật, Đại học Đông Hải, Đài Loan, Trung ương, \\ Số 1727, ngõ 4, Đại lộ Đài Loan, quận Xidun, Đài Trung 40704
}

Tóm tắt: Đạo luật Tiêu chuẩn Lao động Đài Loan (LSA), được ban hành ngày 30 tháng 7 năm 1984, là luật quan trọng nhất bảo vệ người lao động tại Đài Loan. Và chỉ sau khi LSA được thông qua thì các nghiên cứu có hệ thống về luật lao động mới thực sự bắt đầu. LSA là một đạo luật tương đối mới với nhiều quan niệm không được chắc chắn, do đó, bằng cách thực thi đạo luật này, chúng phải đối mặt với nhiều khó khăn. Đối với điều này, cơ quan tư pháp đóng vai trò quyết định. Tuy nhiên, theo thông lệ, thẩm phán thường trích dẫn các ý kiến của các học giả để ủng hộ quyết định của mình. Trong bài này, tác giả sẽ giải thích cách thức cơ quan tư pháp đang hợp tác với các học giả để đưa ra những câu trả lời tốt hơn, đặc biệt là bảo vệ người lao động, thông qua việc xác định "người lao động", "người sử dụng lao động", đối với các vấn đề liên quan đến tiền lương, giờ làm việc và việc sa thải. Nhìn chung, chúng tôi đồng ý với một học giả người Đức nổi tiếng Gallmmilscheg đã nói "Richterrecht bleibt unserer schicksal" ("Tư pháp vẫn là số phận của chúng ta") và các học giả cũng sẽ đóng góp cho điều này.

Từ khóa: LSA, người lao động, người sử dụng lao động, lương, thời giờ làm việc, sa thải. 